\title{
AUTOMATIC CONTROL SYSTEMS
}

UDC 629. 735.05: 621.38(045),

DOI: $10.18372 / 1990-5548.52 .11864$

\section{${ }^{1}$ A. P. Kozlov, \\ ${ }^{2}$ O. S. Yurchenko}

\section{ONBOARD MONITORING SYSTEM OF GROUND AIRCRAFT DOWNLOAD}

Educational \& Research Institute of Information and Diagnostic Systems, National Aviation University, Kyiv, Ukraine

E-mails: ${ }^{1}$ ap_kozlov@ukr.net, ${ }^{2}$ ayurchenko@yahoo.com

\begin{abstract}
Analysis of aircraft ground loading process is given. The need to measure the weight of the loaded characteristics of the aircraft is shown. Brief overview of chassis construction and characteristics of its deformation of the support piece is shown. It is proposed to combined construction device for measuring deformations of the support piece with capacitive transducers. Conditions for implementation of monitoring system for ground aircraft download are considered.
\end{abstract}

Index Terms-Weight measurements; chassis design; load monitoring systems.

\section{INTRODUCTION AND PROBLEM STATEMENT}

When loading the aircraft proper stowage and securing reliable it is essential for safety. Placement of cargo on the plane should not shift the position of its center of mass (alignment) of range. Placement of cargo from the boundary alignment value degrades the stability and controllability of the aircraft, doing weight off and landing, increases the load on the pilot, to a certain extent affect the fuel consumption. Analysis of the causes and circumstances of many emergency situations shows that the availability of the actual alignment of the front outside of the permissible value increases the rate of descent. One reason for this uncertainty is ground loading.

Calculation of alignment and load the plane carries traffic service organization. The main document for calculating alignment, when loading the aircraft "Manual centering download" (MCD). Formulas and download charts in this document are shown. At airports, where this service is not available, the center of gravity position calculation holds crew and the work load of the ship and cargo consolidation Loader airport under the supervision of one of the crew members. Work on verification of serviceability and preparing to use the on-board handling equipment, its maintenance and repairs carried out by employees of aero technical base (ATB). Ground measurement of factual weight characteristics and to determine the alignment of the loaded airplane is unfortunately absent. Necessary to develop and implement on-board systems of technical means for monitoring the weighting characteristics of the aircraft after it is downloaded.

With a view to finding ways of solutions this problem the methods and technical means to deter- mine the total weight of the aircraft and its alignment are considered.

Review and analysis of existing technical means for weighing shows, that weighing of aircraft is performed by ground aircraft scale with electronic display, such as the BAT-23. Aerial scale divided on platform and rack (mounted on racks). Determination of weight characteristics is performed for an empty or fueled the aircraft after its manufacture or repair at the factory and is recorded in the aircraft logbook.

\section{DEVELOPMENT OF THE ONBOARD SYSTEM}

Aircraft scales are intended for determination mass aircraft and location the alignment of airplanes and helicopters. Strain gauges of aircraft scales provide electrical signal in the form of a voltage proportional to the measured weight of the aircraft, after it signals introduced to a computer, where they are processing.

The data allow us to calculate the position of the center of gravity of the aircraft. The result can be reflected on a computer monitor. In particular, constructed and operated weighbridge for AN-2 aircraft, the An-24, -26, -30, -32, Mi-2 and Ka-26, and rack the weight for the An-12, An-24, An -26, Yak-40, IL-76. For SOEs "Antonov" designed rack scales for super heavy aircraft carrying up to 300 tons.

All considered devices are ground and placed in the factory hangars. For control weighting characteristics of the aircraft after calculated load after the voyage it is necessary to develop measuring deformation based on the definition of basic parts of the chassis. Consider the typical constructions of the typical chassis of the aircraft.

As seen in Fig. 1. all designs have a cylindrical part (1),which determine the deformation of the chassis load [1]. 


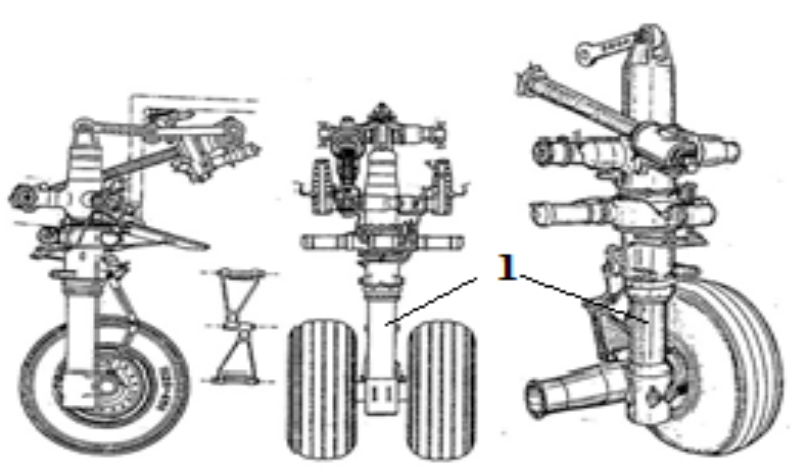

$\mathrm{a}$

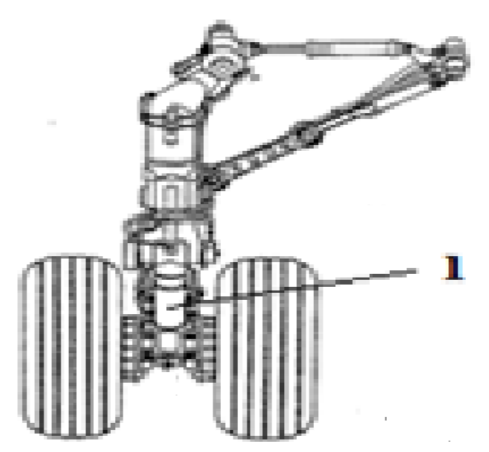

b

Fig. 1. The constructions of chassis: (a) front landing gear; (b) chassis side: 1 is the cylindrical part chassis

Consider the deformation of the cylindrical parts (Fig. 2). When the load force $F$ decreases its length $l$, the diameter increases. The maximum increase is in his mid-parts $x_{0} \quad \varepsilon_{l}$ relative to the longitudinal and transverse deformation $\varepsilon_{s}$ carrying information about the load size $F$ [3].

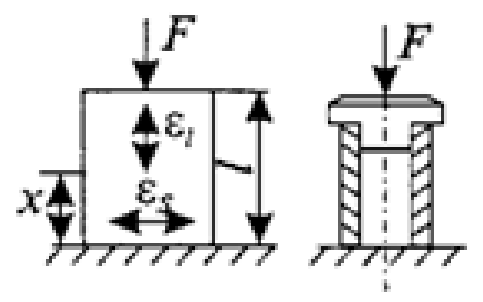

Fig. 2. The deformation of the cylindrical part

To solve the problem is proposed use capacitive transducers. The construction of longitudinal deformation sensor with a capacitive transducer (Fig. 3) is considered. In the upper fixed core delighted with the electrodes of the capacitive transducer. In the lower fixed fastened grounded rod. His move changes the balance of electromagnetic fields two capacitors included in the scheme of transformer bridge [2]. Unbalance signal carries information about the amount of deformation rack.

To convert strain into an electrical signal often used gage sensors. But on the chassis of the aircraft often affect shock loads. This occurs when boarding the aircraft, especially during rough landing, the rolling-out an emergency landing at the limit bandwidth, if the path to ground aircraft traffic accident foreign objects.

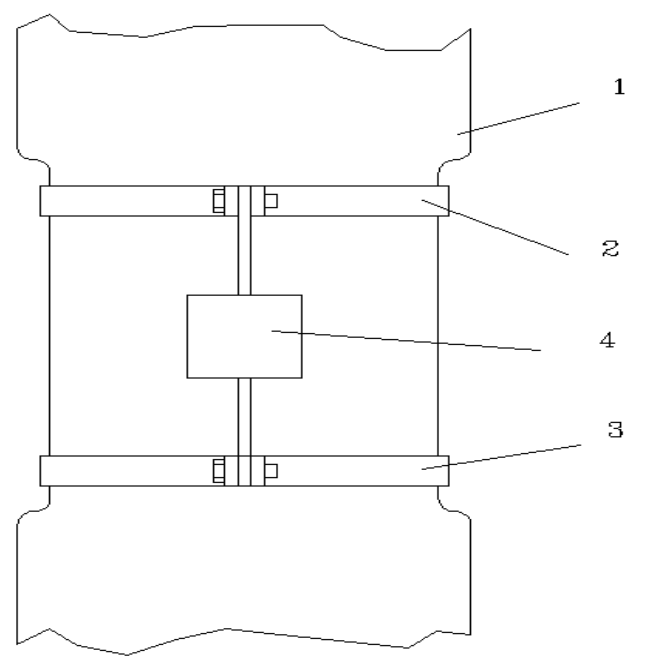

Fig. 3. Construction of the sensor longitudinal deformation of the cylindrical chassis parts: 1 is the cylindrical part of the chassis; 2 is the upper fastener; 3 is the bottom fastener; 4 is the capacitive transducer

In this same cylinder on the opposite side of the transverse strain sensor is placed. Its design (Fig. 4) consists of 3 elastic metal rings pressed against the surface of the cylinder and fastened together. The end of the lower elastic element attached to the rod, the other end is attached to the lower delighted.

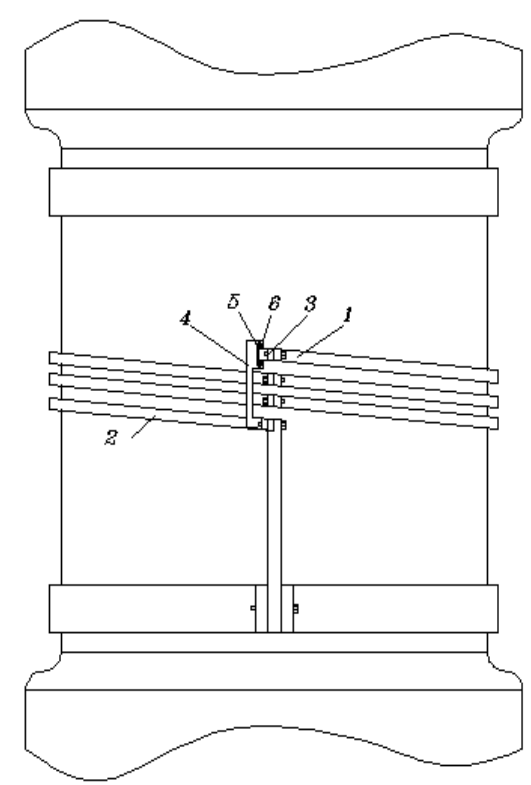

Fig. 4. The design of the sensor transverse deformation of the cylindrical chassis parts: 1 is the upper annular elastic element; 2 is the lower annular elastic element; 3 is the rolling grounded electrode capacitive transducer; 4 is the piece placed on high potential electrode capacitive transducer; 5, 6 is the high potential electrode capacitive transducer 
The final surface of the upper elastic element, when no load, is on the base line parallel to the axis of the cylinder. When loading gear cylinder diameter increases and the final surface elastic element deviates from the baseline. Distance deviation is about the size of the rack chassis deformation, and it is about load. To measure the variation applied capacitive transducer. At the upper end of the rod that is fixed on the lower part attached fastener at the upper end of which is placed capacitive transducer design. It consists of two high potential electrodes placed on the bottom plate and the low potential electrode placed on the plate with high potential electrodes.

Rolling grounded electrode capacitive transducer is placed between them. In the absence of abnormalities transformer bridge circuit is connected to this differential capacitor balanced. The load causes deformation rack chassis and unbalance the bridge.

The design has the following features. If some load increase the radius of the cylinder in the control reaches 1 micron $\left(10^{-6} \mathrm{~m}\right)$, rejecting one elastic element from baseline to $6.28 \mu \mathrm{m}$, and 3 elements $27.84 \mu \mathrm{m}$. That is, this design has a sensitivity of about 30 times higher.

As discussed above in determining the weight of the aircraft and its alignment on aviation scales obtained information is transmitted and processed by computer. The calculated data can be displayed on the monitor. This equipment and the structure of the system can be used in the developed onboard monitoring system ground aircraft loading. The necessary electrical signals from strain gauges rack chassis and front right and left landing gear converted to discrete form and send in an onboard computer. The program of processing and imaging data is introduced by crew members.

Also consider the impact of weather conditions: wind, rain, snow. To avoid these effects is proposed to use a mobile hangar as a collapsible structure, covered with a tarpaulin. Upon entry into the hangar front and rear curtain is lowered. This hangar is most expedient to place the edge of the taxiway, where and load the aircraft before takeoff. If this is a passenger aircraft, the exercise load control and possibly correct the alignment.

A load control system onboard the aircraft will significantly improve safety. Measuring strain landing gear will allow the state to exercise control design of the chassis and prevent the possibility of damage [4]. Capacitive transducers have high sensitivity and allow measurements of sufficiently small displacement.

The implementation of monitoring system for ground aircraft download is advisable.

\section{CONCLUSION}

Based on the existing technical means to control weight characteristics of the aircraft, methods and technical means are considered for determination of the total weight of the aircraft and its alignment. A combined structure of meter design strains with capacitive transducers is proposed.

\section{REFERENCES}

[1] V. L. Belsky, I. P. Vlasov, N. V. Zaitsev and others, Aircraft structures. Moscow, Oborongiz, 1965, 710 p.

[2] Transformer measuring bridges. Under the Under the general revision of Member-cor. AS USSR. B. Karandeeva. Moscow, Energia, 1970, 280 p.

[3] E. S. Polishchuk, M. M. Dorozhovets and others. Metrology and Measuring Equipment. Lviv, Publishing House "Beskid troubles," 2003, 544 p.

[4] A. P. Kozlov, "The control strain critical aircraft structures." Electronics and Control Systems, vol. 2(5), pp. 41-46, 2007.

Received January 10, 2017

Kozlov Anatoliy. Candidate of Science (Engineering). Assosiate Professor.

Educational \& Research Institute of Information and Diagnostic Systems, National Aviation University, Kyiv, Ukraine. Education: Kiev State University named T. G. Shevchenko, Kyiv, Ukraine (1965).

Research interests: Capacitive transducers with non-uniform electromagnetic field. Capacitive meters of parameters small altitude of the flight aircraft. The use of capacitive transducers in automatic control small-altitude of the flight aircraft.. Publications: 48.

E-mail: ap_kozlov@ukr.net

Yurchenko Alexander. Candidate of Science (Engineering). Assosiate Professor.

Educational \& Research Institute of Information and Diagnostic Systems, National Aviation University, Kyiv, Ukraine. Education: Moscow Phisics-thechnical Institute, Moscow, Russia (1975).

Research area: operating system, dynamic allocation memory.

Publication: 56.

E-mail: ayurchenko@yahoo.com 


\section{А. П. Козлов, О. С. Юрченко. Бортова система контролю наземного завантаження літака}

Описано аналіз процесу завантаження літака. Показано необхідність вимірювання вагових характеристик. Наведено короткий огляд конструкцій шасі та характеристик деформацій опорної деталі. Пропонується комбінована конструкція вимірювача деформацій опорної деталі з ємнісними перетворювачами. Розглянуто умови впровадження системи контролю параметрів завантаження.

Ключові слова: вимірювання вагових характеристик; конструкція шасі; системи контролю параметрів завантаження.

Козлов Анатолій Павлович. Кандидат технічних наук. Доцент.

Навчально-науковий інститут інформаційно-діагностичних систем, Національний авіаційний університет, Київ, Україна.

Освіта: Київський державний університет ім. Т. Г. Шевченка, Київ, Україна (1965).

Напрям наукової діяльності: ємнісні перетворювачі 3 неоднорідним електромагнітним полем. Смнісні прилади вімірювання геометричних параметрів маловисотного польоту повітряного судна. Використання ємнісних перетворювачів в системах автоматичного керування маловисотним польотом повітряного судна.

Публікації: 48.

E-mail: ap_kozlov@ukr.net

Юрченко Олександр Сергійович. Кандидат технічних наук. Доцент.

Навчально-науковий інститут інформаційно-діагностичних систем, Національний авіаційний університет, Київ, Україна.

Освіта: Московський фізико-технічний інститут, Москва, Росія (1975).

Напрям наукової діяльності: операційні системи, динамічний розподіл пам’яті.

Кількість публікацій: 56.

E-mail: ayurchenko@yahoo.com

\section{А. П. Козлов, А. С. Юрченко. Бортовая система контроля наземного загрузки самолета.}

Описан анализ процесса загрузки самолета. Показана необходимость измерения весовых характеристик. Приведен краткий обзор конструкций шасси и характеристик деформаций опорной детали. Предлагается комбинированная конструкция измерителя деформаций опорной детали с емкостными преобразователями. Рассмотрены условия внедрения системы контроля параметров загрузки.

Ключевые слова: измерения весовых характеристик; конструкция шасси; системы контроля параметров загрузки.

Козлов Анатолий Павлович. Кандидат технических наук. Доцент.

Учебно-научный институт информационно-диагностических систем, Национальный авиационный университет, Киев, Украина

Образование: Киевский государственный университет им. Т. Г. Шевченко, Киев, Украина (1965).

Направление научной деятельности: емкостные преобразователи с неоднородным электромагнитным полем. Емкостные устройства измерения геометрических параметров мало высотного полета воздушного судна. Использование емкостных преобразователей в системах автоматического управления мало высотным полетом воздушного судна.

Публикации: 48.

E-mail: ap_kozlov@ukr.net

Юрченко Александр Сергеевич. Кандидат технических наук. Доцент.

Учебно-научный институт информационно-диагностических систем, Национальный авиационный университет, Киев, Украина.

Образование: Московский физико-технический институт, Москва, Россия (1975).

Направление научной деятельности: операционные системы, динамическое распределение памяти.

Количество публикаций:56.

E-mail: ayurchenko@yahoo.com 